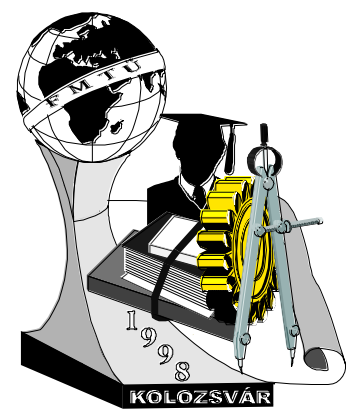

FIATAL MÜSZAKIAK TUDOMÁNYOS

ÜLÉSSZAKA

Kolozsvár, 1998. március 20-21.

\title{
Acélfelület keménységének növelése lézeres felületátolvasztással
}

\author{
Bitay Enikö, Dr. Roósz András
}

\begin{abstract}
An usual technology in case of the structural material to change the properties of the surface (i.e. the hardness) of tough basic material is to change the structure and/or the composition of the surface by a surface treatment method. One of the most modern technologies is the laser surface treatment. At a given composition the required properties are available by well determined parameters of laser beam (i.e. beam power, beam velocity). The goal of this work is to study of the effect of these parameters on the hardness of a case hardening steel.
\end{abstract}

\section{Bevezető}

A koptatásnak kitett szerkezeti anyagok egyik szokásos gyártástechnológiája, hogy a szívós anyagból készített alkatrész felületének szerkezetét és/vagy összetételét és ezáltal a felületi réteg tulajdonságait (elsősorban a keménységét) valamilyen felületkezelési eljárással megváltoztatják. A legkorszerübb eljárások egyike a lézeres felületkezelés. Adott anyagösszetételnél a jól meghatározott paraméterek segítségével (lézersugár teljesítmény, pásztázó sebesség, stb.) elérhetők a kívánt tulajdonságok. E tanulmány célja eme paraméterek tanulmányozása egy betétben edzhető acélfelület keménységének növelése érdekében lézeres felületátolvasztással.

\section{Lézeres felületátolvasztás}

A lézeres felületátolvasztásnál a felületre bocsátott nagy energia hatására a fém megolvad és néhány $\mathrm{mm}^{3}$ térfogatú olvadék tócsa alakul ki. A lézeresen megolvasztott tócsa alakjának jellemző adatai a szélesség és mélység (1.ábra). 

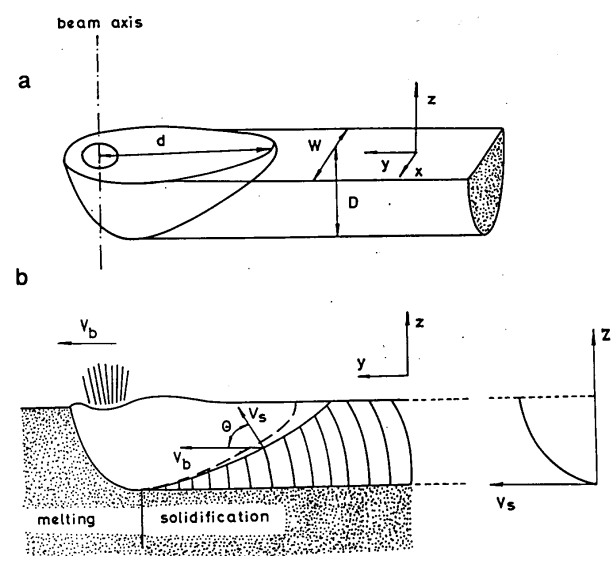

\section{1. ábra}

Az átolvasztott tócsa geometriája, [1]

A tócsa mélysége függ a lézersugár teljesítményétől, a pásztázó sebességtől, a sugárátmérőtől, valamint az anyag reflektáló képességétől és a hőelvonásától, röviden szólva a egységnyi idő alatt az egységnyi térfogatban maradó energiától. Grafit bevonással csökkenthető a reflekció, s így az átolvasztott sáv mélysége megnövelhetö. A gyors dermedés $\left(10^{4} \sim 10^{6} \mathrm{~K} / \mathrm{s}\right)$ következtében a felületi réteg tulajdonságai megváltoznak. A hülési sebességet adott sugárparaméterek mellet az olvadéktócsa alatti alapanyag hődiffúziós tényezője és a hőmérséklet gradiens határozza meg [1,2].

A felületi réteg kémiai összetétele nem tér el az alapanyagétól, viszont a lézeres átolvasztás során a kéreg rendkívül keménnyé, kopásállóvá válik, valamint javulhat a korróziós tulajdonsága is. Az elönyök mellett számolnunk kell azzal is, hogy adott esetben az átolvasztott rétegben a nagy maradó feszültségek repedést esetleg törést is okozhatnak.

\section{Kísérletek}

A lézeres kezelést a budapesti Bay Zoltán Anyagtudományi Intézet (BAYATI) laboratóriumában végeztük egy TRUMF gyártmányú TLC105 típusú, maximum $5 \mathrm{~kW}$ teljesítményü $\mathrm{CO}_{2}$ lézerrel. Vizsgálati alapanyagként a C15-ös betétben edzhető acélt használtunk (összetétele 0,16\%C; 0,50\% \%n; 0,27\% \% $0,024 \% \mathrm{~S} ; \quad 0,016 \% \mathrm{P})$. A próbatest mérete $57 \times 57 \times 15 \mathrm{~mm}$, felülete síkköszörült, grafittal futtatott volt. A kísérletnél 1, 2, 3 illetve $5 \mathrm{~kW}$ sugárteljesítményt és 300, 500, $700 \mathrm{~mm} /$ perc pásztázó sebességet alkalmaztunk. Minden paraméter beállítással 3-3 kísérletsorozatot végeztünk. A kísérlet folyamán létrehoztunk egyedi sávokat a jelenség megismerése céljából valamint átlapolt sávokat a lehetséges technológia tanulmányozása érdekében. 


\section{Mérés ek}

A kísérletek kiértékelését a Miskolci Egyetem Anyagtudományi Intézet laboratóriumába végeztük. Az anyag keresztmetszetéből a vizsgálathoz probadarabokat készítettünk. A kialakult felületi réteget a keresztmetszetben vizsgáltuk Neophot 2 típusú fénymikroszkoppal. A darabban az alábbi három rész különböztethető meg (2. ábra) : átolvadt övezet, hőhatás övezet, eredeti szerkezet.

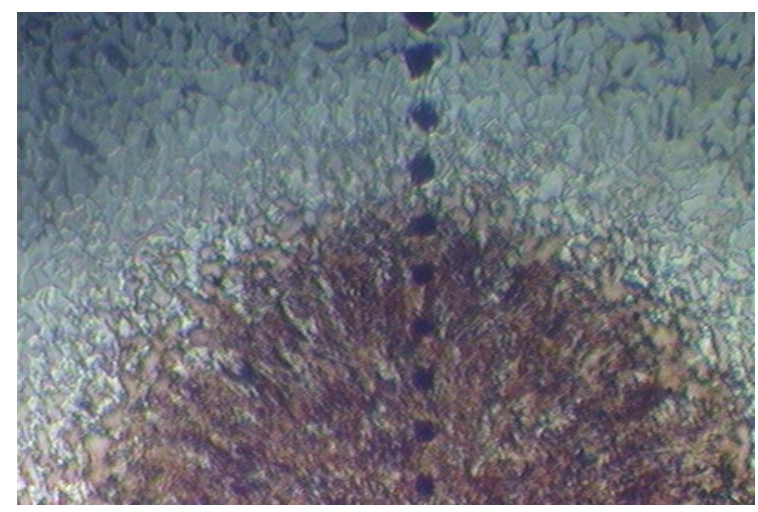

2a. ábra

A próba szerkezete egyedi sávok esetében

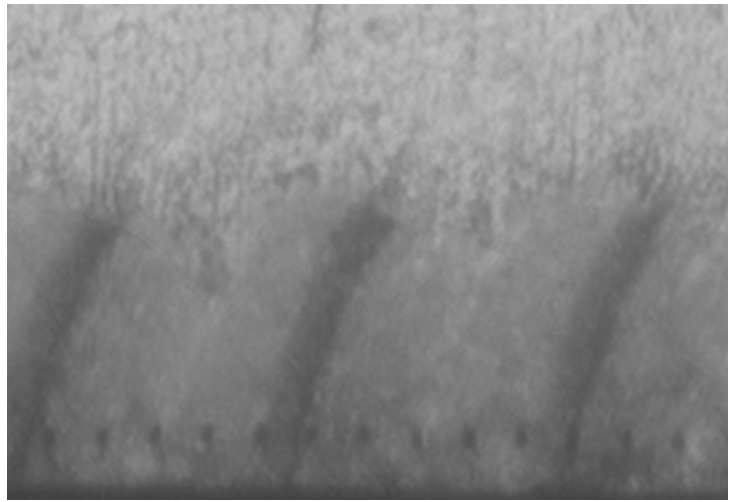

2b. ábra

A próba szerkezete az átlapolt sávok esetében

Lemértük az egyedi sávok szélességét, mélységét. A különböző sugárteljesítmények mellet a pásztázó sebesség függvényében a sáv mélységének változását a 3. ábra szemlélteti .

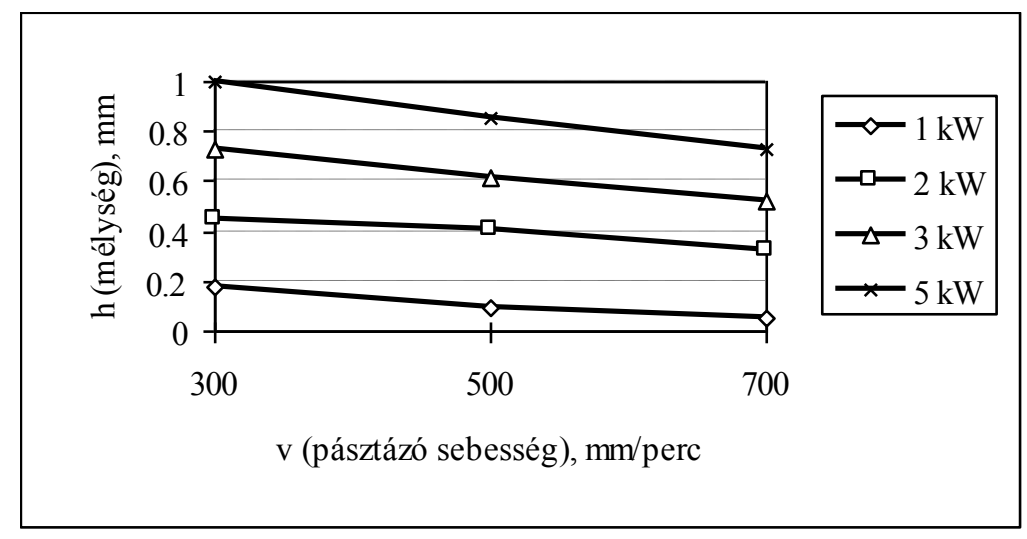

\section{3. ábra}

Atolvasztott tócsa mélysége a pásztázó sebesség függvényében

A próbadarabokon végeztünk keménységmérést mind a felülettel párhuzamosan $0,15 \mathrm{~mm}$ mélységben mind a felületre merőlegesen az átolvasztott sáv középvonalában. A méréshez Reichert típusú keménységmérőt használtunk 300g terheléssel (4. és 5. ábra). 


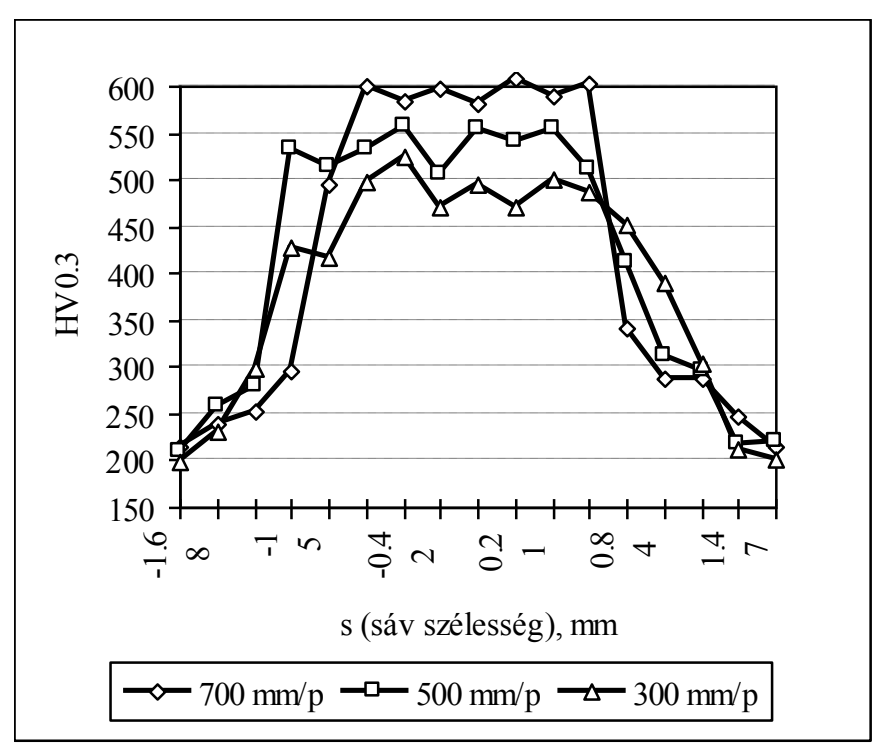

\section{4. ábra}

Keménységeloszlás az átolvasztott sáv szélességében

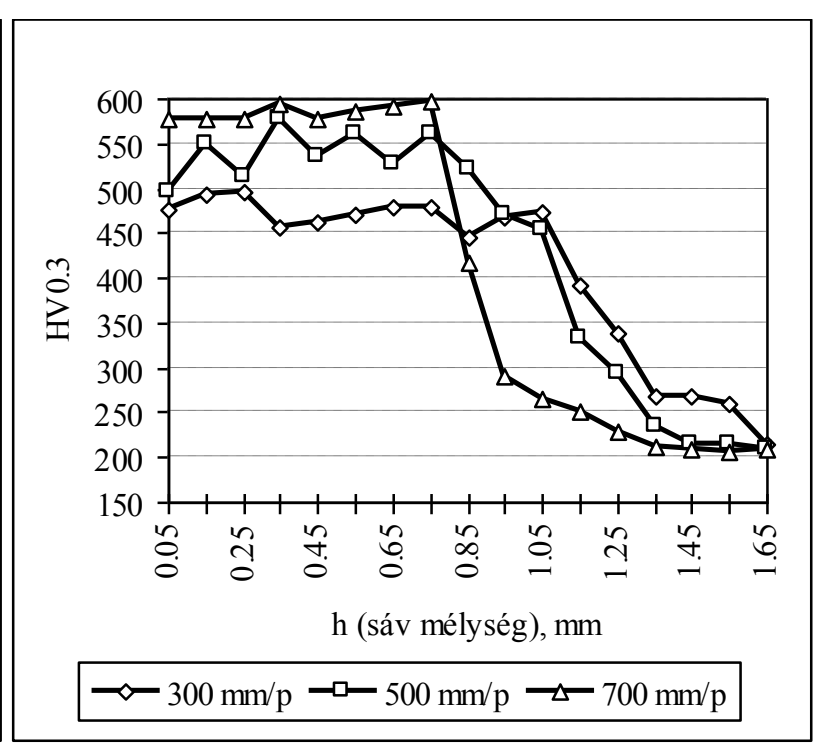

5. ábra

Keménységeloszlás az átolvasztott sáv mélységében különbözö pásztázó sebesség mellett

\section{Kiértékelés}

A mérések alapján a következöket állapítottuk meg:

(1) A sugárteljesítmény növekedésével az átolvasztott tócsa mélysége és szélessége jelentősen nő míg a pásztázási sebesség növekedésével kismértékben csökken;

(2) Az átolvasztás hatására a felületi réteg keménysége nagymértékben megnőtt (a kiinduló szerkezet keménysége $200 \mathrm{HV}_{0.3}$ volt, az átolvasztott rétegé 400 és $700 \mathrm{HV}_{0.3}$ között változott);

(3) Az átolvasztott zóna maximális keménysége a sugárteljesítmény és a pásztázó sebesség növekedésével jelentősen nőtt.

\section{Irodalom}

[1] Roósz A., Rozsnoki 1., Teleszky I., Uray Gy., Sólyom J., Gácsi Z., Kovács Á., Baán M. : Modification of hot working steel surface by laser treatment.

The 7th International Conf. on Surface Modification Technology, Niigata, Japan, 1993okt.31.- nov.3

[2] Teleszky I.: Lézeres felületkezelés, Tanulmány, Miskolci Egyetem Anyagtudományi Intézet, 1996.

Bitay Enikő, doktorandusz a Kolozsvári Müszaki Egyetemen munkahely: SC Tehnofrig SA, Kolzsvár, E-mail: bitay@,usa.net

Roósz András, DSC, Professzor, Miskolci Egyetem

E-mail: femroosz@gold.uni-miskolc.hu 